\title{
Public and Private in Jewish Egodocuments of Amsterdam (ca. 168o-183o)
}

\author{
Michaël Green
}

The early modern Netherlands saw several important changes that demonstrated the development of a growing need of what nowadays we would call 'privacy.' ${ }^{1}$ In architecture, the extensive use of the corridor allowed restricted access to individual rooms. ${ }^{2}$ In the cultural realm, the surge of the so-called egodocuments (which to be classified as such need to contain the personal pronoun ' $I$ ') demonstrates the need to document one's private life. These records were intended for personal use, for the instruction of the future generations or as social justification. ${ }^{3}$ Amsterdam was the largest city of the newly independent United Provinces of the Netherlands, and it was home to numerous religious minorities, including Catholics, Lutherans, and Jews. ${ }^{4}$ This article focuses on the latter group due to the unique situation of Jews in the

* The author expresses his gratitude to Tirtsah Levie Bernfeld, Christina Griffiths, Tsila Rädecker, Mette Birkedal Bruun, Tom-Eric Krijger, and Lars Cyril Nørgaard for commenting on the earlier versions of this article, as well as to the colleagues at the Centre for Privacy Studies, and to the participants of the symposiums "Privacy in Early Modern Jewish Life" held at the Centre on 17 February 2020 and "Privacy in Judaism" held at the Institute for Jewish Studies, Jagiellonian University in Cracow on 24 April 2019 for the fruitful discussions. The article was written with the support of the Danish National Research Foundation Centre for Privacy Studies within the framework of the grant DNRF 138. All translations from Dutch are mine unless otherwise noted.

1 The word 'privacy' appeared in the Dutch language only in the late nineteenth century. See: Green M., "Spaces of Privacy in Early Modern Amsterdam", Tijdschrift voor Sociaale en Economische Geschiedenis 18.3 (2021) 17-40.

2 Van den Heuvel Ch., 'De Huysbou': A Reconstruction of an Unfinished Treatise on Architecture, Town Planning and Civil Engineering by Simon Stevin (Amsterdam: 2005). For the emergence of privacy in Dutch architecture and Stevin's take on it, see De Mare H., Huiselijke taferelen: de veranderende rol van het beeld in de Gouden Eeuw (Nijmegen: 2012).

3 Dekker R., "Introduction", in Dekker R. (ed.) Egodocuments and History: Autobiographical Writing in its Social Context since the Middle Ages (Hilversum: 2002) 7-20.

4 Frijhoff W. - Prak M. (eds.), Geschiedenis van Amsterdam, vol. 2-1: Centrum van de wereld, 1578-1650 (Amsterdam: 2004). 
United Provinces, where they enjoyed a relatively peaceful life, unlike in other European countries.

Egodocuments are sources that reveal the authors' perceptions of various aspects of life, including at times their most intimate thoughts. ${ }^{5}$ For this reason, they are an important source for the study of privacy. However, the researcher needs to approach such sources with caution: egodocuments may often reflect expectations, trends, and ideals rather than the author's true perceptions. ${ }^{6}$ Out of the twenty-three egodocuments listed in the most recent edition of Repertorium, a register of Dutch egodocuments, just four were written by members of the Jewish community in Amsterdam. ${ }^{7}$ According to Jonathan Israel, there were only 350 Jews in Amsterdam in 1610, i.e. o,4\% of the city's population. By the mid-eighteenth century, Jews (both Ashkenazi and Sephardim) numbered ca. 20,00o (of a total population of ca. 250,000), which equals $10,5 \%$ of the population. ${ }^{8}$ Hence, even if the Repertorium cannot be considered exhaustive, the number of extant egodocuments produced in the Jewish community is considerably lower than in the rest of the population [Fig. 10.1].

After an overview of the Jewish history of Amsterdam and an outline of the methodology, I will examine three egodocuments written by Jews in Amsterdam in the seventeenth, eighteenth, and early nineteenth centuries respectively. Thus, the aim is to sketch notions of privacy as they come to the fore in these three sources that represent different historical periods and different genres: the family history of Isaac de Pinto (1629-1681), written in ca. 168o with the aim of justifying the Jewish heritage; the chronicle of Abraham Chaim Braatbard (1699-1786), written in the mid-eighteenth century, in which the author relates his own experiences and those of fellow Jews as a community; the memoirs of Moses Salomon Asser (1754-1826), written in the early nineteenth century, and reflecting on his personal success story. J.H. Chajes distinguishes several types of medieval egodocuments in the Jewish context, such as the pinkas (ledger book), the kuntres (a quire of five sheets in which explorative texts were written), and the megillah (scrolls containing notes or teachings). These different modes of medieval self-expression formed the basis for those in the early

5 Ariès Ph., "Introduction", in Ariès Ph. - Duby G. - Chartier R. (eds.), A History of Private Life, vol. 3, trans. A. Goldhammer (Cambridge, MA - London: 1989) 5 .

6 See also Laflamme's contribution to this volume.

7 Dekker R. - Baggerman A. (eds.), Egodocumenten van Nederlanders uit de zestiende tot begin negentiende eeuw. Repertorium (Amsterdam: 2016).

8 Israel J.I., "The Republic of the United Netherlands Until About 1750: Demography and Economic Activity", in Blom J.C.H. - Fuks-Mansfeld R.G. - Schöffer I. (eds.), The History of the Jews in the Netherlands (Liverpool: 2007) 85-115, here 100. 


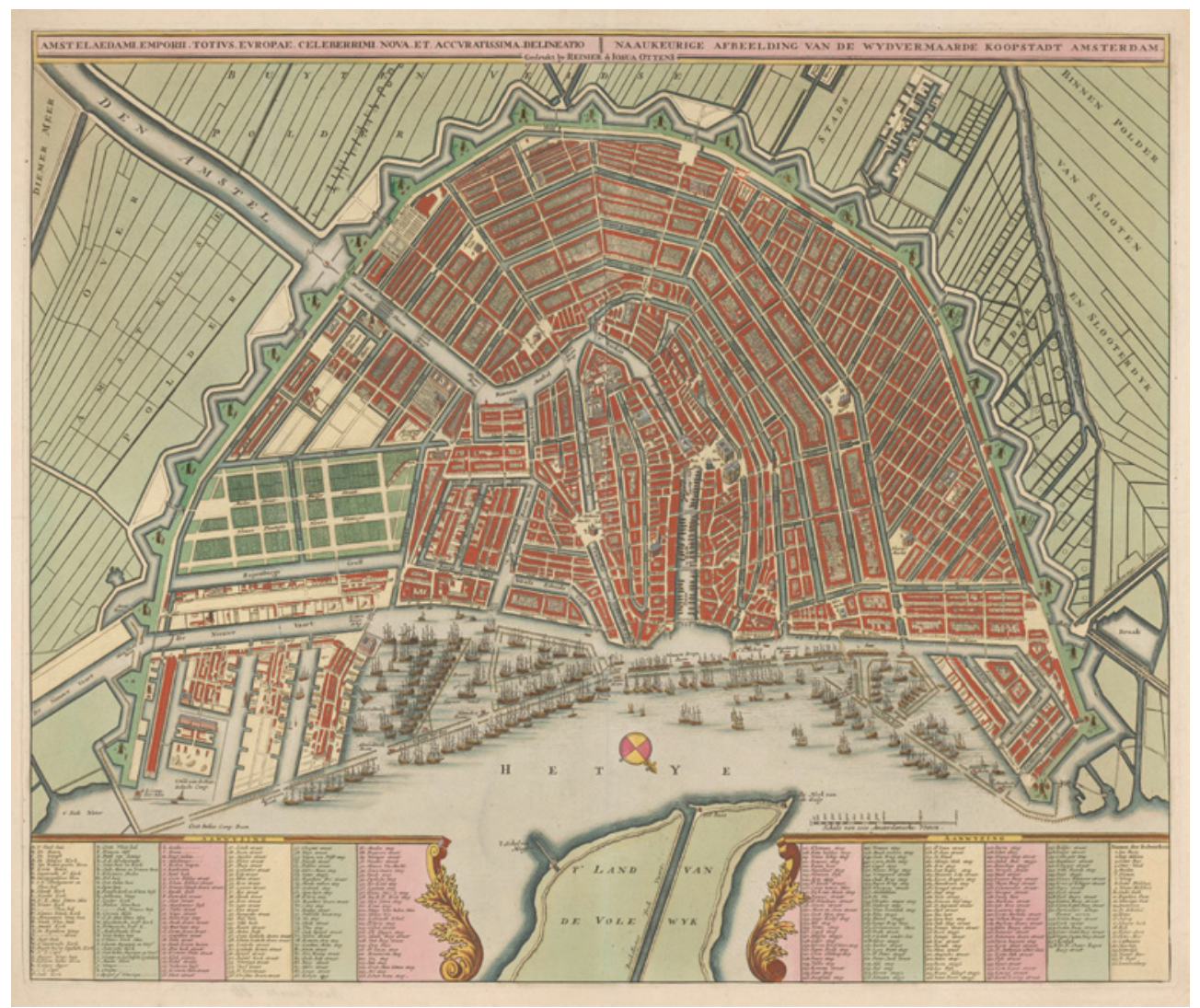

FIGURE 10.1 Anonymous, Map of Amsterdam, 1726-1750. Engraving, $48,3 \times 58,3 \mathrm{~cm}$

(C) RIJKSMUSEUM AMSTERDAM, OBJ. NUMBER: RP-P-AO-20-55-3

modern period. ${ }^{9}$ Concerning the megillah, Chajes states that it included works 'that never entered the public domain because of the controversial nature of their contents', since they at times contained 'individual opinions..$^{10}$ According to Avriel Bar-Levav, certain early modern Jewish egodocuments stem from the genre of ethical wills in which 'the author gives moral instruction to his children or to other readers.'1 This is indeed the case in the text of De Pinto and Asser, but less so for Braatbard's text, which is rather similar to the chronicle

9 Chajes J.H., "Accounting for the Self: Preliminary Generic-Historical Reflections on Early Modern Jewish Egodocuments", The Jewish Quarterly Review 95.1 (2005) 1-15, here 15.

$10 \quad$ Ibidem, 6.

11 Bar-Levav A., "'When I was Alive': Jewish Ethical Wills as Egodocuments", in Dekker R. (ed.), Egodocuments and History: Autobiographical Writing in its Social Context since the Middle Ages (Rotterdam - Hilversum: 2002) 45-59, here 46. 
of a Christian Dutchman: Jacob Bicker Raye (1703-1777), who also wrote about himself with the broader community in view. ${ }^{12}$ These documents testify to the contemporary Jewish way of life and thought. The three sources are of course not exhaustive, and this article presents a first attempt to deal with the concept of privacy as it appears in Jewish egodocuments from Amsterdam.

\section{$2 \quad$ Jews in Early Modern Amsterdam}

The Jewish community of Amsterdam traces its origins to the late sixteenth century. By the early seventeenth century, the authorities had become concerned with the arrival of the Jews. In 1615, the famous jurist Hugo Grotius (1583-1645) and a pensionary of Amsterdam Adriaen Pauw (1585-1653) were asked by the States of Holland and of West Friesland to give practical advice on the admittance of Jews into the country. ${ }^{13}$ The two men belonged to the two major Protestant movements of the time: Remonstrants and Counter-Remonstrants, so the choice indicated the will of the provincial government to find a solution that would be acceptable to everybody. ${ }^{14}$ The Portuguese or Sephardic Jews were the first to establish their new home in the city as they fled from the Spanish and Portuguese persecution. Some arrived in the late sixteenth century, but the majority arrived after $1600 .{ }^{15}$ German Jews arrived after the break of the Thirty Years War and due to economic hardship. Their community was officially established in $1635 \cdot{ }^{16}$ Polish (and Lithuanian) Jews arrived between 1648 and $1666 .{ }^{17}$ The German and the Polish Jewish communities merged in 1673 into one Ashkenazi community, which was referred to as 'Hoogduitse'

12 Bicker Raye Jacob, Het dagboek van Jacob Bicker Raye 1732-1772, eds. F. Beijerinck M.G. de Boer (Amsterdam: 1935).

13 Grotius Hugo, Hugo Grotius's Remonstrantie of 1615. Facsimile, Transliteration, Modern Translations and Analysis, trans., eds. D. Kromhout - A. Offenberg (Leiden: 2019). Pauw's text is lost.

14 Ibidem, $5^{2}$.

15 For an overview of the situation of the Jews in the United Provinces, see Bodian M., Hebrews of the Portuguese Nation: Conversos and Community in Early Modern Amsterdam (Bloomington, IN: 1997). On the Sephardic Jews specifically, see: Fuks-Mansfeld R.G., De Sefardim in Amsterdam tot 1795. Aspecten van een joodse minderheid in een Hollandse stad (Hilversum: 1989); Kaplan Y., "The Portuguese Community in 17th-century Amsterdam and the Ashkenazi World", in Michman J. (ed.) Dutch Jewish History: Proceedings of the Fourth Symposium on the History of the Jews in the Netherlands 7-10 December - Tel-AvivJerusalem, 1986, vol. 2 (Assen - Maastricht: 1989) 23-46.

16 Kaplan Y., "Amsterdam and the Ashkenazi Migration in the Seventeenth Century", Studia Rosenthaliana 23 (1989) 22-44, here 23, 38.

17 Ibidem. 
(High-German)..$^{18}$ Already in 1654, the Jews could obtain 'minor citizenship', which gave them permanent resident status but no rights equal to those of the Dutch Reformed. ${ }^{19}$ According to David Sorkin, Jews 'were excluded from retail trade and most crafts, public office and the ability to pass their privilege to their children.' ${ }^{20}$

The Sephardic community to which Isaac de Pinto, the author of our first example, belonged was richer and better embedded in Amsterdam's urban milieu than the Ashkenazi community to which the other two authors belonged. ${ }^{21}$ At the same time, the Sephardic community aimed to establish its prominent position in the city, with the synagogue, the Esnoga, built as its symbol in 1675. The Great Ashkenazi synagogue had been established four years earlier, ${ }^{22}$ and these two places of worship, built by the same Dutch architect, Elias Bouman (1636-1686), were located opposite one another, separated by the Muidergracht canal [Figs. 10.2-10.3]. ${ }^{23}$

Despite the rather tolerant climate of the early modern United Provinces, one of the Jews' constant fears was that of persecution and pogroms since these

18 On the Ashkenazi community of Amsterdam, see Sluys D.M., "Hoogduits-Joods Amsterdam van 1635 tot 1795 ", in Brugmans H. - Frank A. (eds.), Geschiedenis der Joden in Nederland, vol. 1 (Amsterdam: 1940) 306-381; Berger Sh., "Reading Yiddish and Lernen: Being a Pious Ashkenazi in Amsterdam, 1650-180o", in Kaplan Y. - Michman D. (eds.), The Religious Cultures of Dutch Jewry (Leiden - Boston: 2017) 124-140. For a broader overview on the Ashkenazi Jews in the Netherlands, see Wallet B., Links in a Chain: Early Modern Yiddish Historiography in the Northern Netherlands (1743-1812) (Ph.D. dissertation, University of Amsterdam: 2012). A curious late eighteenth-century source regarding the community has been preserved: Zwiers A., "Inventory of the Moveable Property of the Ashkenazi Community of Amsterdam, 1788”, Studia Rosenthaliana 37 (2004) 309-397, here 309 .

19 Sorkin D., "Beyond the East-West Divide: Rethinking the Narrative of the Jews' Political Status in Europe, 16oo-1750", Jewish History 24 (2010) 247-256, here 249.

20 Sorkin, "Beyond the East-West Divide" 249. On legal status of the Jews: Huussen A.H., "The Legal Position of the Jews in the Dutch Republic c. 1590-1796", in Israel J. - Salverda R. (eds.), Dutch Jewry: Its history and Secular Culture (1500-2000) (Leiden: 2002) 25-42.

21 This does not mean that the Sephardic community did not have its share of the poor, see Levie Bernfeld T., Poverty and Welfare Among the Portuguese Jews in Early Modern Amsterdam (Oxford: 2012).

22 Both synagogues are listed in the Beschryvinge van Amsterdam, which includes the buildings in Amsterdam in 1694, in between the 'Menniniste Kerk der Waterlanders' and the 'Het Rasp, of Tucht-Huys'. See Commelin Isaak, "Beschryving der stadt Amsterdam, vervattende alle desfselfs oude en nieuwe gebouwen", in Casparus Commelin (ed.), Beschryvinge van Amsterdam (Amsterdam, bij de Wed. Aart Dirksz Oossaan: 1694) book 4, 252.

The Muidergracht was since covered up, and nowadays there is just a regular street. 


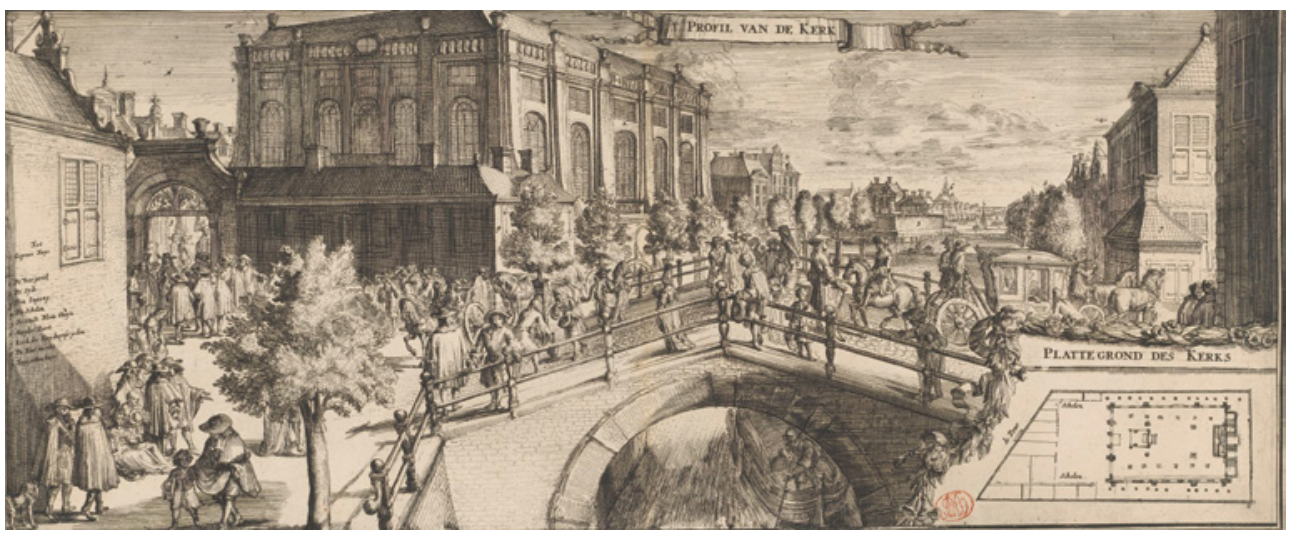

FIG URE 10.2 Romeyn de Hooghe, View on the Portuguese Synagogue in Amsterdam, Amsterdam, ca. 1695 . Engraving, 24,1 ×56,8 cm

(C) RIJKSMUSEUM AMSTERDAM, OBJ. NUMBER: RP-P-AO-24-26

were part of their collective past and present in various places in Europe. ${ }^{24}$ Hence, the Sephardim decided to open the doors of their synagogue to gentiles in order to demonstrate how the services were actually performed. ${ }^{25}$ This decision has a particular importance for the understanding of notions of privacy: Jewish prayers do not usually allow the presence of non-Jews. Yet, the leading members of the community saw the act of opening the doors of the synagogue as a means of saving lives: the breach of privacy and the disregard of religious prescriptions happened in the name of security and survival of the community.

In the later seventeenth century, Amsterdam became not only a commercial centre but also a centre of Jewish culture and thought. ${ }^{26}$ In that period,

24 For an account of persecution in Ukraine, see Teller A., "Jewish Women in the Wake of The Chmielnicki Uprising: Gzeies Tah-tat as a Genered Experience", in Cohen R.I. Dohrmann N.B. - Shear A - Reiner E. (eds.), Jewish Culture in Early Modern Europe: Essays in Honour of David B. Ruderman (Cincinnati, OH: 2014) 39-49. For an overview of the persecution by the Portuguese Inquisition throughout the early modern period, see Costigan L.H., "The Rise of the Modern Inquisition in Portugal and Brazil, and the Transformation of Jews and New Christians into Heretics", in Prudlo D. (ed.), A Companion to Heresy Inquisitions (Leiden: 2019) 228-245.

25 Kaplan Y., "Gente Política: The Portuguese Jews of Amsterdam vis-à-vis Dutch Society", in Brasz Ch. - Kaplan Y. (eds.), Dutch Jews as Perceived by Themselves and by Others: Proceedings of the Eighth International Symposium on the History of the Jews in the Netherlands (Leiden - Boston - Cologne: 2001) 21-40.

26 See the recent study by Bendowska M. - Doktór J., The Amsterdam of Polish Jews: Old Hebrew Printed Works from the Collections of the Jewish Historical Institute Warsaw (Warsaw: 2016). 


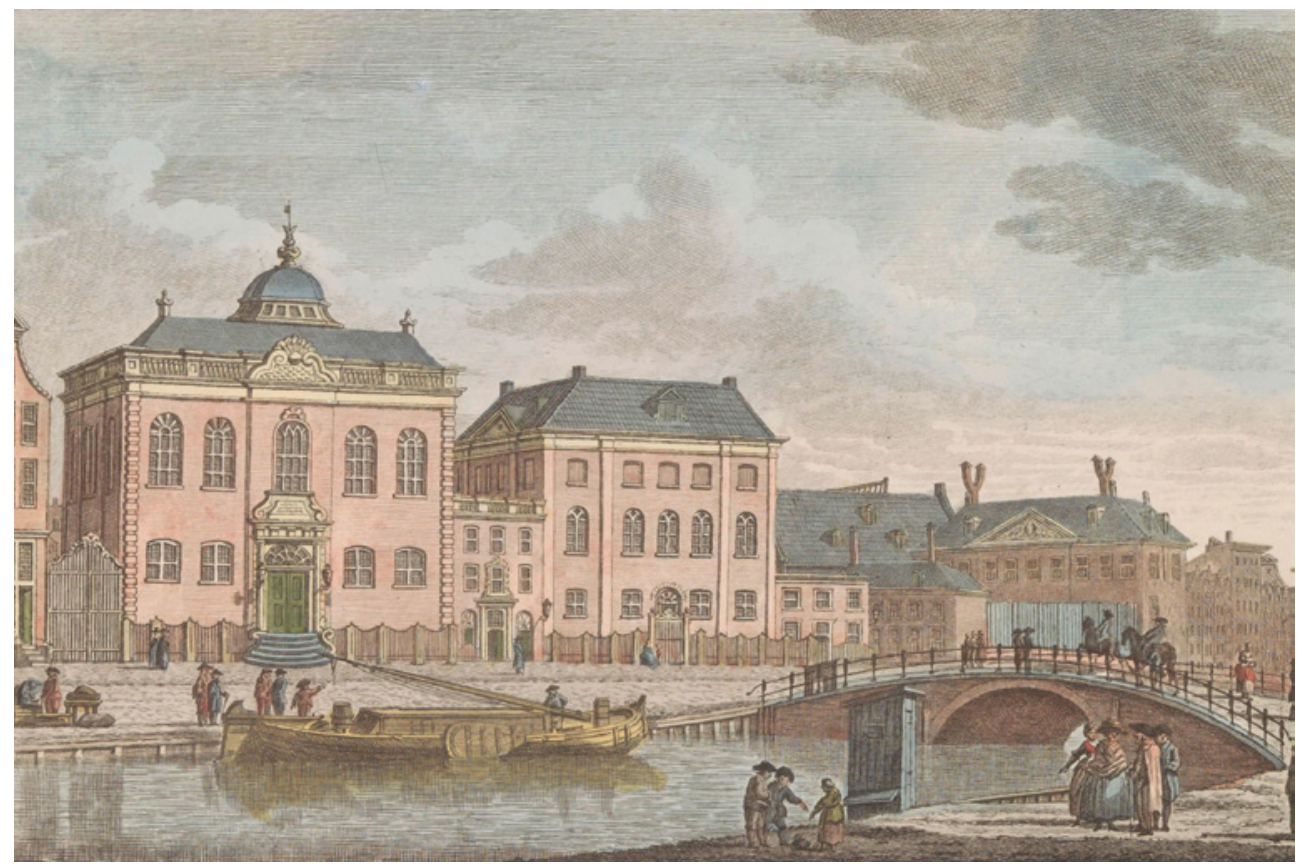

FIGURE 10.3 Carel Frederik Bendorp after Jan Bulthuis, Ashkenazi (Hoogduitse) Synagogue in Amsterdam, Amsterdam, ca. 179o. Engraving, $17,4 \times 25 \mathrm{~cm}$

(C) RIJKSMUSEUM AMSTERDAM, OBJ. NUMBER: BI-B-FM-116-7

some representatives of the Jewish community accumulated significant wealth, often through their participation in the Dutch colonial enterprises. Consequently, the Jewish leadership in Amsterdam was striving to improve their own individual legal position as well as that of the Jews in the United Provinces in general. ${ }^{27}$ Yet, equality was only achieved during the Batavian Republic, when Moses Solomon Asser (1754-1826) petitioned the National Assembly to recognise the Jews as full citizens in March $1796 .{ }^{28}$ We shall return to Asser, who authored the last egodocument discussed below.

27 On Jewish merchants, see Schreuder Y., Amsterdam's Sephardic Merchants and the Atlantic Sugar Trade in the Seventeenth Century (Newark, DE: 2019); Israel J.I., "The Changing Role of the Dutch Sephardim in International Trade, 1595-1715", in Michman J. - Levie T. (eds.), Dutch Jewish History: Proceedings of the Symposium on the History of the Jews in the Netherlands November 28-December 3, 1982, Tel Aviv-Jerusalem (Jerusalem: 1984) 31-52.

28 Sonnenberg-Stern K., Emancipation and Poverty: The Ashkenazi Jews of Amsterdam, 17961850 (Houndmills - London: 200o) 36 . 
In the Dutch context, the word 'privacy' appears only at the turn of the twentieth century. ${ }^{29}$ Therefore, we find no Dutch sources speaking explicitly about 'privacy' by using the term. Rather, the sources point to the issue through their context. Accordingly, the goal here is not to engage with existing theories on what privacy was at the time, but rather to probe into the ways in which notions of privacy come across. ${ }^{30}$ We should keep in mind that there is no stable definition of privacy either in our contemporary or in the early modern context. ${ }^{31}$ One useful definition of privacy in the early modern context can be that of Mary E. Trull, who depicts it as 'a pleasurable freedom from certain kinds of observation, but this early modern sense of "privacy" indicates the shared freedom of familiarity rather than freedom of isolation'.32 This definition is particularly useful when working with egodocuments pertaining to friendship, family, and communal relationships. Two or more people can create a 'private nexus, ${ }^{33}$ which allows them to exchange ideas freely without the physical presence of others. Building upon this understanding of early modern privacy as a working definition, this article is guided by the methodology developed at Centre for Privacy Studies, which uses heuristic zones of privacy that map out the early modern world - soul/mind, body, bedroom, house/household, community, and state. ${ }^{34}$ The soul/mind represents the innermost zone and the state represents the outermost zone. Privacy can exist within each of these zones, but also in overlaps or thresholds, where one zone interferes with another - for example, the state with the mind, or the community with the household. As such, according to S.T. Margulis, privacy also refers to the levels of access: the access to oneself, to the community, or to information about

29 Various aspects of the English word 'privacy' are covered in Dutch, as for example in French, with separate notions: privé-leven (private life), geheimhouding (confidentiality), bedektheid (secrecy).

30 There is only a limited amount of secondary literature on Dutch privacy in the early modern context, see Wheelock (Jr.) A.K. - Seeff A.F. (eds.), The Public and Private in Dutch Culture of the Golden Age (Newark - London: 200o); Schuurman A. - Spierenburg P. (eds.), Private Domain, Public Inquiry: Families and Life-styles in the Netherlands, 1500 to the Present (Hilversum: 1996).

31 In her introductory chapter to this volume, Mette Birkedal Bruun surveys the various definitions given by contemporary researchers of early modern privacy.

32 Trull M.E., Performing Privacy and Gender in Early Modern Literature (Houndmills: 2013) 8.

33 My term.

34 Bruun M.B., The Centre for Privacy Studies Working Method, online edition, accessed on 25 June 2020. <https://teol.ku.dk/privacy/research/work-method/privacy_work_method . pdf $>$. 
these two can be regulated by increasing or decreasing privacy. ${ }^{35}$ To elaborate on this, a private zone can be created by a person, by a group of people, or even by a certain community by preventing access to their physical place - home, church, synagogue, town - or by not sharing their thoughts and ideas. By using heuristic zones as a map, and keeping in mind the idea of the levels of access, this article attempts to trace notions of privacy in the egodocuments written by Jews in Amsterdam.

\section{"De Pinto Manuscript" by Isaac de Pinto (1629-1681): The Privacy of a Family}

De Pinto's chronicle is one of the oldest surviving egodocuments of the Jewish community in Amsterdam. The Dutch historian H.P. Salomon took the trouble of reconstructing the entire text based on five surviving manuscripts and translating it into English. ${ }^{36}$ De Pinto's family was one of the most prominent families of Portuguese Jews and part of the city's Sephardic community. Shortly after their flight from Antwerp in 1646, they initially settled in Rotterdam. From there, Isaac I de Pinto and some of his family moved to Amsterdam, home to a major Portuguese Catholic community. The family became one of the most prominent merchant families in Amsterdam. ${ }^{37}$ The De Pinto manuscript is a family chronicle written in Amsterdam, in which Isaac de Pinto tells the story of his family from his great-great-grandparents to himself, including the detailed account of the family's flight from Antwerp. ${ }^{38}$ Such a family history aims to restore the Jewish legitimacy of the family as back in Antwerp the family was Catholic.

The story of De Pinto offers interesting glimpses into the family's perceptions of privacy. Having described in detail the family's positions in Portugal, Isaac de Pinto reaches his own story, coinciding with the last years of the Eighty Years War (the Dutch War of Independence). It seems that the political and financial conditions led the family to think that it was time to flee to

35 Margulis S.T., "Privacy as a Social Issue and Behavioral Concept", Journal of Social Issues 59.2 (2003) 243-261, here 246.

36 Salomon H.P., "The 'De Pinto' Manuscript: A 17th Century Marrano Family History”, Studia Rosenthaliana 9.1 (1975) 1-62.

37 Ibidem, 6-7.

38 For the chronicle and the De Pinto family, see Bodian, Hebrews of the Portuguese Nation 38-42. More on Isaac De Pinto: Berger Sh., "Isaac de Pinto's Testament: A Case of Multiple Images?", in Brasz Ch. - Kaplan Y. (eds.), Dutch Jews as Perceived by Themselves and by Others (Leiden - Boston: 2001) 79-91. 
a place where they could practise Judaism, the religion of their ancestors, to which they felt a sense of belonging. In 1646, most of the De Pinto family left Antwerp and moved to the United Provinces, where their relatives awaited them. Isaac de Pinto travelled separately for safety reasons as the country was at war with France.

Such a journey, undertaken in secret, points to the first instance of what could be considered as privacy. On his way to Rotterdam, De Pinto stops in Turnhout, a town caught between the Dutch and the French forces. There he meets a certain man named Bastiao, his 'neighbour', who comes to him and takes him 'aside, alone. ${ }^{39}$ De Pinto writes that this man called him his 'friend', saying that 'he was informing me of this [danger from the approaching French forces and the need to flee as soon as possible, MG], for he well knew that I would keep it secret'.40 Secrecy is a side path of privacy, and it points at a close confidential bond between two or more people. ${ }^{41}$ Also, friendship allows private moments between people ${ }^{42}$ with various degrees of trust. Indeed, Bastiao as a former neighbour belongs to the community in which De Pinto lived in Antwerp, part of this communal space that shares a certain degree of trust. Here, by establishing this link, Bastiao creates a private zone with De Pinto, a safe place where he can feel confident and allow access to himself. They both make use of this zone in order to safely continue their journey.

However, what other notions of privacy can we deduce from our source? Home is one of the most frequently referred to spaces in egodocuments, as the following examples will show. It is also one of the heuristic zones of privacy. As a place of residence, home is closely connected with the notion of family. As Chris Berks points out, the English philosopher John Locke (1632-1704) defines family 'as a domain of privacy, as separate from the state, but crucially also separate and distinct from the society around it'.43 While home was not a place of seclusion for most of the population, especially for the bourgeoisie and upper echelons of society, it was the place where the individual and the family resided. Lena Cowen Orlin argues that the early modern home was far from what nowadays we would consider private, because of possible observation both from outside and within the house. ${ }^{44}$ Yet, its structure which developed throughout the period offered some secluded spaces. ${ }^{45}$ More importantly,

39 Salomon, "De Pinto" 33.

40 Ibidem, 34.

41 See chapters by Frijhoff and Safley in this volume.

42 Trull, Performing Privacy 8.

43 Berg Ch., The Classical Liberal Case for Privacy in a World of Surveillance and Technological Change (Cham: 2018) 84.

44 Cowen Orlin L., Locating Privacy in Tudor London (Oxford: 2007) 10.

45 Berg, The Classical Liberal Case for Privacy 77-78. 
the entrance to the house was controlled, often by the wife, and therefore the access, if referring back to the definition given by Margulis, was limited, based on the wishes of the owner. ${ }^{46}$ Therefore, the house offered a certain degree of safety and privacy to its residents.

In fact, De Pinto refers to home on several occasions. On one of them, De Pinto writes that when he and his family reached the neutral town of Zevenbergen,

we found, outside of town, at about rifle range, a castle, or, rather, a large old house, which we rented and to which we moved. But as the terrain there is low, swampy, and very humid, it was a most unhealthy place to live $[\ldots][\mathrm{w}] \mathrm{e}$ spent three months, more or less, in that castle, very uncomfortably, it being an old and unhealthy place. When my mother fell terribly ill there, as well as my sister and my late beloved cousin, we were troubled and afflicted by the lack of decent doctors. ${ }^{47}$

After referring to the place as an old house and then actually as a castle, the author informs us twice that the place was old and unhealthy, with all the negative impressions imaginable. As a result of living in such a place, his relatives suffered from illnesses. This gives the impression that the house that they rented was not considered home. ${ }^{48}$ It was not a secure and safe haven for the family where they could recuperate before continuing their journey. Rather, it was a place where they were forced to stay because of lack of other options.

As the security conditions deteriorated, the family decided to go directly to Rotterdam and settle there. De Pinto writes that they arrived in the town of Moerdijk near Amsterdam, where his mother's cousin met them and made them throw away all their provisions because he was afraid these were not kosher. ${ }^{49}$ This act is symbolic of giving up on their not-so-Jewish past and accepting the new strict rules of the Jewish community of Rotterdam. We can see it as a threshold where the community is imposing its will and rules on an

46 Flather A., Gender and Space in Early Modern England (Woodbridge: 2007) 44.

47 Salomon, "De Pinto" 36.

48 Alan Levine points out that for Montaigne to be 'chez soi' (at home) is the only way for a person to feel pity and compassion, while going outside brings insensitivity to the other. For Montaigne the two concepts of the 'home' and the 'self' are connected - one needs to be in touch with the self, and the notion of home is used to connect 'the existing reality'. See: Levine A., "Skepticism, Self, and Toleration in Montaigne's Political Thought", in Levine A. (ed.), Early Modern Skepticism and the Origins of Toleration (Lanham - Boulder New York - London: 1999) 51-77, here 65; Levine A., Sensual Philosophy: Toleration, Skepticism, and Montaigne's Politics of the Self (Lanham - Boulder - New York - London: 2001) 151 .

Salomon, "De Pinto" 38. 
individual family. They are required to live as Jews among Jews, to become part of the community, people that could be trusted.

In Rotterdam, the family stopped at the house of Abraham Soares, which is described as a 'very fine, large house'.50 The house that was rented for them was on the contrary 'very small [...], because in such a short time they [their people in Rotterdam] couldn't [sic] find anything else. ${ }^{51}$ Curiously, although coming with the intention to live as Jews, De Pinto particularly mentions that they were not showing any signs of being Jewish outside their house nor telling anyone they were Jews, yet they learned Hebrew and Jewish traditions. This was a typical situation for New Christians, (the Spanish and Portuguese Jews who were forced to convert to Christianity) upon their return to Judaism - Jews on the inside, within the privacy of their home, and Christians on the outside because of the fear of persecution. ${ }^{52}$ Yet the situation quickly changed and they eventually became full members of the Portuguese Jewish community because the situation in the United Provinces allowed them to exercise Judaism freely.

Being Jewish has a direct influence on one's body: the male members of the family had to be circumcised. The mohel, a professional circumciser, was sent from Amsterdam and circumcised six people in one day. De Pinto refers to the bodily discomfort they suffered as the healing process lasted longer because of cold weather. Bodily privacy became increasingly important in the early modern period as people were less and less keen to be touched or observed. ${ }^{53}$ Yet, keeping in mind the religious importance of the circumcision of the Jews, this community interference with the body of the believer was the price of becoming its full participant. ${ }^{54}$

There, in Rotterdam, Isaac de Pinto married his cousin Rachel de Pinto Henriques (?-1652), with whom he had a child in 1652 . After his wife died soon after childbirth, he writes that '[i]n May 1653 I moved with my household and my son to Amsterdam'.55 There he married another cousin, Rachel da Veiga (?-?). In Amsterdam, the De Pinto family bought the famous 'De Pinto House', which still stands on the Breestraat [Fig. 10.4].

\footnotetext{
$50 \quad$ Ibidem, 38 .

$5^{1}$ Ibidem.

$5^{2}$ Schreuder, Amsterdam's Sephardic Merchants 7-12; Bodian, Hebrews of the Portuguese Nation 38-42.

53 Tarlow S., Ritual, Belief and the Dead in Early Modern Britain and Ireland (Cambridge: 2011) 62 .

54 Salomon, "De Pinto" 39-40.

55 Ibidem, 44 .
} 


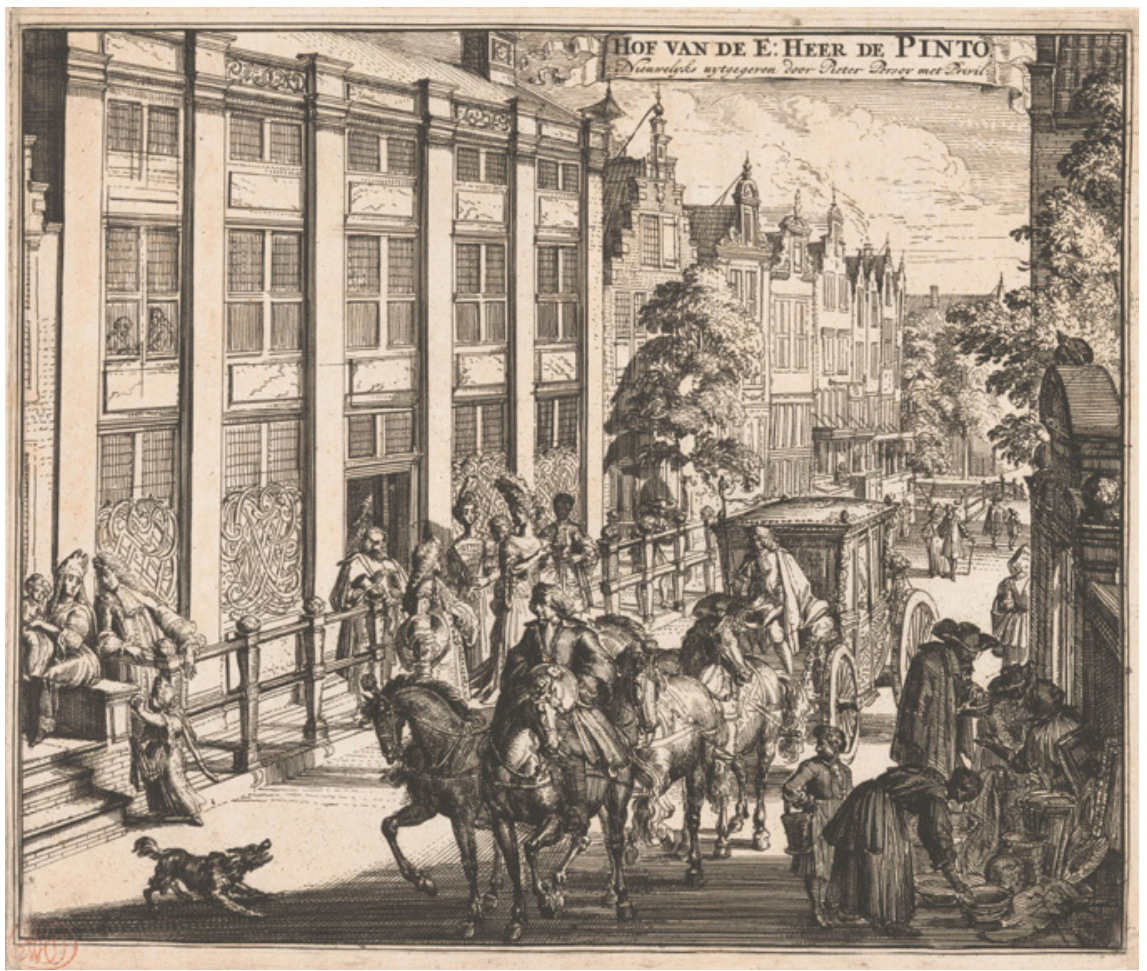

FIGURE 10.4 Romeyn de Hooghe, House of David de Pinto on Sint-Antoniesbreestraat in Amsterdam, Amsterdam, ca. 1695. Engraving, $24 \times 28,4 \mathrm{~cm}$

(C) RIJKSMUSEUM AMSTERDAM, OBJ. NUMBER: RP-P-AO-25-74-1

\section{"Ein neye kronik" by Abraham Chaim Braatbard (1699-1786): Privacy - a Look from the Outside}

Abraham Braatbard or by his Jewish last name Heiman, son of Tswi Hirsch, was born in Amsterdam in 1699 and died there in 1786, at the respected age of eighty-seven. He married Sipra Hyman (1704-?) in 1729 and they lived with their nine children at the Houtgracht. His "Ein neye kronik" spans the period of $1740-175^{2}$ and chronicles events of daily life. ${ }^{56}$ Being of the Ashkenazi

$56 \quad$ Parts of it were edited and translated into Dutch from the original Yiddish in 196o by Leo Fuks, and this is the text to which I will refer here. The biographical references are taken from this work: Fuks L., De zeven provinciën in beroering. Hoofdstukken uit een Jiddische kroniek over de Jaren 1740-1752 van Abraham Chaim Braatbard (Amsterdam: 1960). See in particular the introduction: 7-14. See also Michels E., Jiddische Handschriften der Niederlande (Leiden - Boston: 2013) 300-305. 
community, he wrote Yiddish but used it only phonetically: according to his modern editor, he did not belong to the well-educated elite of the community. ${ }^{57}$ The focus of Braatbard's "Kronik" is different to De Pinto's family history. His interest in writing such a document could have been sparked by his previous (and perhaps continuous) employment as a typesetter for Hebrew books in Amsterdam. ${ }^{58}$ Indeed, the chronicle stops in 1751 , shortly after he had taken over his father's financial enterprise. ${ }^{59}$ This document paints a very interesting picture of the life of Jews in Amsterdam during a period that led to the reinstatement of the Stadtholderate in Holland as Willem IV (1711-1751) became stadtholder in $1747{ }^{60}$ As Ariane Zwiers asserts, 'Braatbard certainly wrote his chronicle for a wider audience, or at least for his children and grandchildren'. ${ }^{61}$ This rather unclear assertion points to the fact that this text was not written for the author's use only.

When reading his text, the influence of the Jewish community upon its individual members stands out. We are also confronted with the attempts of Jewish individuals to establish better connections with the Dutch state in the face of the stadtholder. Thus, the Jewish affinity of the author comes forward in his focus on the Jewish participation in Dutch life, which we can use to try to decipher the delicate communal privacy of the Jewish community. Braatbard explains that, as part of the celebrations for the installation of Willem IV as Stadtholder in May 1747, people were wearing orange ribbons on their clothes to show their support for the Prince of Orange. He writes that 'a lot of money was earned by the Jews on the orange ribbons. No one dared at the time to go without an orange ribbon on the street' ('Er werd door de Joden zeer veel geld met oranjelinten verdiend. Niemand durfde immers zonder oranjelint op straat'). ${ }^{62} \mathrm{He}$ continues by specifying that everyone, without distinction of rank or religion, had to wear one, either on their breast or hat. Some of the more famous Jews dressed up and travelled around Mokum (the Yiddish name for Amsterdam) singing and drinking in honour of the Stadtholder: they even did this in front of the city hall, which would normally cost them a twenty-five

Fuks, De zeven provinciën 7-8; Fuks-Mansfeld R.G., "Abraham Hayim ben Zvi Hirsh Braatbard. A Hebrew Type - Setter in Amsterdam in the First Half of the Eighteenth Century", Zutot 1.1 (2001) 133-137. On the use of Yiddish in Amsterdam, see:Zwiers A.D., "Amsterdam Yiddish in Diary and Chronicle", Studia Rosenthaliana 30.2 (1996) 233-253.

$5^{8}$ Fuks-Mansfeld, "Braatbard" 135.

59 Michels, Jiddische Handschriften 304.

6o Kennedy J.C., A Concise History of the Netherlands (Cambridge: 2017) 245-248. On Willem IV, see: Rowen H.H., "William IV: Neither Revolutionary nor Reformer", in The Princes of Orange: The Stadholders in the Dutch Republic (Cambridge - New York: 1988) 163-185.

61 Zwiers, "Amsterdam Yiddish" 235.

62 Fuks, De zeven provinciën 29. 
guilders fine. ${ }^{63}$ Analysing these events from the privacy perspective, we can see the threshold in which the community, in this case the Dutch community, interfered with the mind of the individuals, who did not voluntarily grant access to their choice of clothing. It is of course common knowledge that an average person on the street had no say in what to wear, but on this occasion, they were pressured by the community and had to pay to conform to the popular demand as those who did not wear orange were beaten up.

Isaac II De Pinto (1717-1787), one of the descendants of Isaac De Pinto of the egodocument discussed above, was one of the most prominent Amsterdam Jews. He was an erudite and the author of several important scholarly works, including the very first one by a Jew in the Netherlands on political economy. ${ }^{64}$ According to Daniel Strum, seeing the deteriorating situation of the Sephardic community in light of the economic crisis of the time due to the decline in trade, Isaac II De Pinto realised that the problem lay in the 'non-economic restrictions that forced the Jewish community to endure a demographic pressure'.65 A member of the Sephardic community and its treasurer, he played an important role in reinstating Willem IV of Orange as stadtholder, mostly by lending him large sums of money to finance his campaign. In return, he expected that the Prince would improve the position of the Jews in the United Provinces. This can explain his support for the Orangist cause. At the same time, we need to keep in mind that while the stadtholder had a high position in the United Provinces, he did not have the absolute power of a king that would allow him to make any political decisions on his own, yet his prestige and influence could help in lobbying the interests of a certain group, in this case the Jews. ${ }^{66}$ Isaac II De Pinto was not unique in his connections with the House of Orange as there are other examples, such as Francisco Lopes Suasso (ca. 1657-1710), a banker who contributed two million guilders to the military campaign of William III during the Glorious Revolution of $1688-1689 .{ }^{67}$

\section{Ibidem, 3 o.}

64 De Pinto was not only a politician, but also a scholar. For biographical details, see Van der Aa A.J., "Pinto (Izaak de)", in Biographisch woordenboek der Nederlanden, vol. 15 (Haarlem: 1872) 326-327. For a more detailed study of De Pinto's work, see Strum D., Princípios da economia política Judaica: as reflexões políticas de Isaac de Pinto (Ph.D. dissertation, Hebrew University of Jersualem: 20oo); Nijenhus I.J.A., Nijenhuis, Een joodse philosophe. Isaac de Pinto (1717-1787) en de ontwikkeling van de politieke economie in de Europese Verlichting (Amsterdam: 1992).

65 Strum, "Isaac de Pinto" 241, and on the economic decline: 237.

66 On stadtholderate and the stadtholders, see:Israel J., The Dutch Republic:Its Rise, Greatness and Fall 1477-1806 (Oxford: 1995) 300-306; Rowen, The Princes of Orange.

67 Troost W., William III, the Stadholder-King: A Political Biography, trans. Grayson J.C. (Aldershot - Burlington: 2005) 195. Today this sum would be equivalent to 23,855.401 euro. The amount is calculated with the help of the calculator of the value of guilder developed 


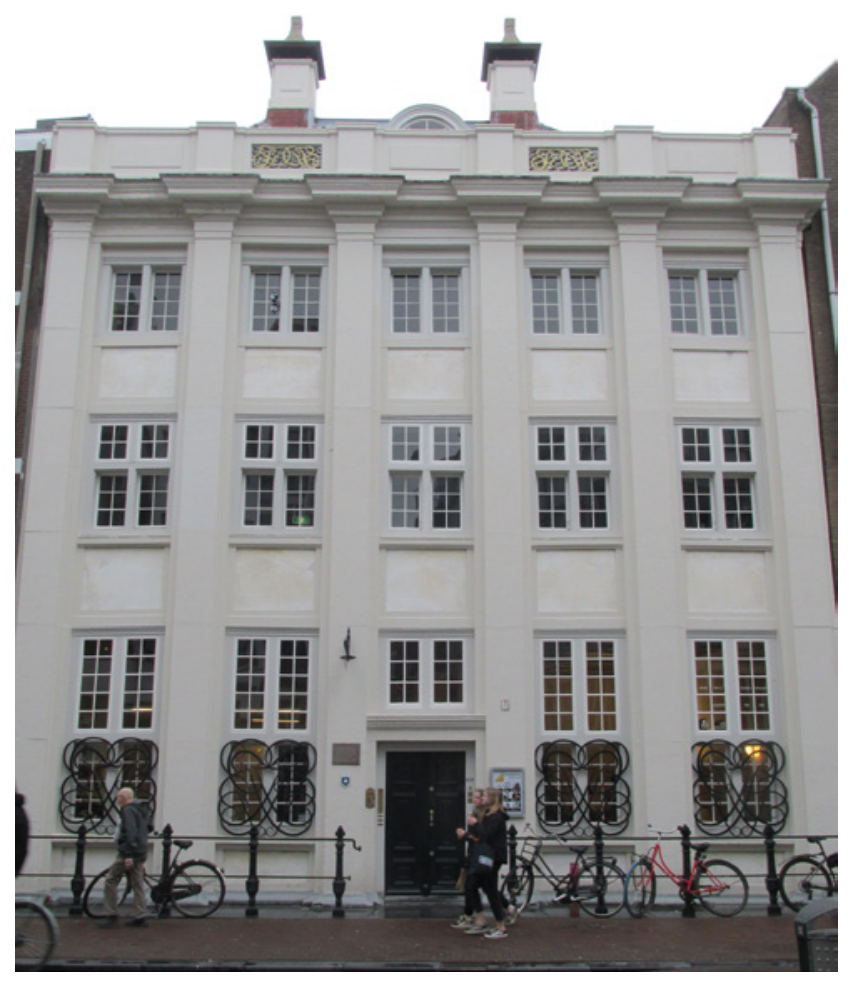

FIGURE 10.5 Michaël Green, House De Pinto - Front, Modern

View, 2020

PHOTOGRAPH. (C) MICHAËL GREEN

Part of De Pinto's attempt to please the stadtholder is depicted by Braatbard. On Tuesday, 3 September 1748 , there was a rumour that De Pinto invited Willem IV to visit him in his house, but the stadtholder did not arrive, because, according to Braatbard, he did not want to pay similar visits to anybody who might ask for them. At the same time, De Pinto's sons frequented the residence of the stadtholder and the guards of the stadtholder were going in and out of De Pinto's home [Figs. 10.5-10.6]. ${ }^{68}$ This point is particularly interesting as the Dutch home, especially among merchants, had a double function. On the one hand, it was a home, a place where a family resided. On the other hand, the

by International Institute of Social History. [Online edition, accessed on 14 April 2020. $<$ http://www.iisg.nl/hpw/calculate.php>].

Fuks, De zeven provinciën 84. 


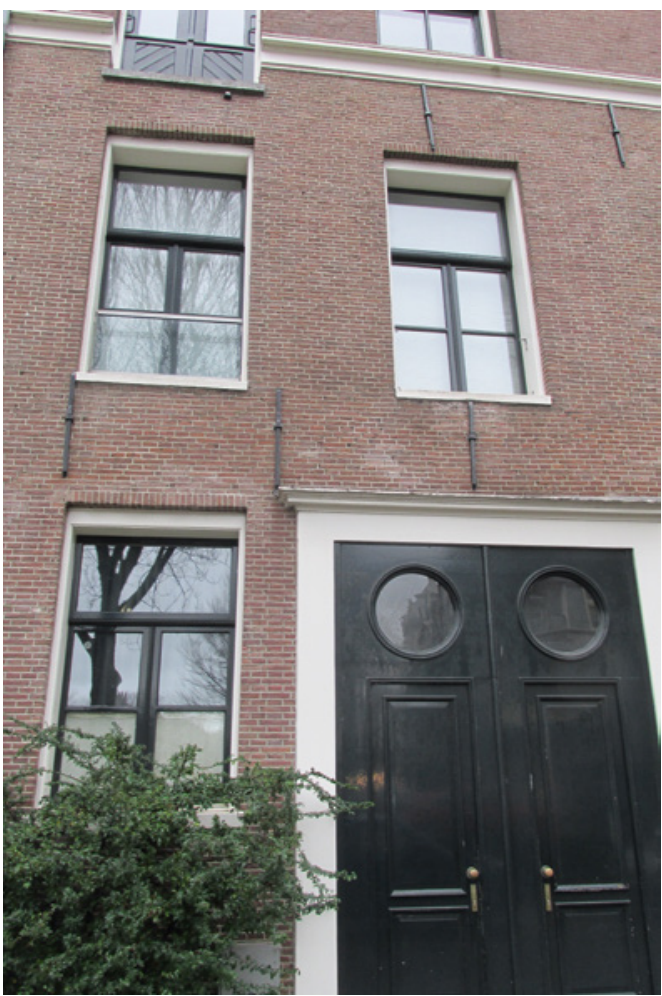

FIGURE 10.6

Michaël Green, House De Pinto Rear, Modern View, 2020

PHOTOGRAPH. (C) MICHAËL GREEN

first floor of the house would often be occupied by a shop and the basement was used for storing goods. ${ }^{69}$ In De Pinto's house, business premises were at the back of the house at the waterfront. Such an invitation points to the will of the host to establish a somewhat better personal connection with the visitor. In this case, Isaac II De Pinto wanted to welcome Willem IV in his own 'private' sphere, where he was in charge, but also where his entire family lived. At the same time, the residence of one of the community elders is not a private house in the way that a home of a milkman is. It is part of the community to which the elder belongs. Looking at the symbolic perspective of the heuristic zones, the Jewish community in the guise of De Pinto was aiming to create a bond with the state in the guise of the stadtholder. This threshold of the community and the state overlaps with the home. The personal relationship between two people, but also between two political entities, is negotiated here.

69 Van den Heuvel, 'De Huysbou'; De Mare, Huiselijke taferelen. 
Coming back to Braatbard's text, the writer's reflection on the writing process is particularly interesting. He writes that it is impossible for him to write about everything that happened in a particular period. He only writes about a particular event, yet he states that he could not remember all the details. ${ }^{70}$ This introspection touches upon the personal dimension, reflecting on his limitations as the person in charge of preserving the information for the future. He also adds another dimension to his writing but frequently refers to certain events that are 'niet te beschrijven' ('not to be described'), or 'niet mogelijk om alles te beschrijven, wat in die tijd gebeurd is' ('impossible to describe in full what happened at the time'). ${ }^{71}$ This can be seen in his reference to the popular riots in Leiden in 1748-1749 on account of taxation, where there was much plunder of property, or in his depiction of the panic at the non-kosher meat hall in Amsterdam, in which a German boy was wounded badly by a cleaver that fell on his foot. ${ }^{72}$ This creates a dramatic effect for the reader, whom Braatbard informs that 'was de angst zo groot, dat het niet te beschreven is' ([t] he fear was that great that it cannot be described). ${ }^{73}$

\section{Mijne Biographie by Moses Salomon Asser (1754-1826): When Private Becomes Public}

Asser's biography was written in February 1823 and it presents a summary of Asser's life. I.H. van Eeghen edited the Dutch original text in 1963 and made it accessible to the research community. ${ }^{74}$ Most known as a member of the maskilim-movement, i.e. Jews influenced by Enlightenment ideas, Asser was a 'self-made jurist' and prosecutor. He took part in writing a codex of laws for the

\footnotetext{
$70 \quad$ Fuks, De zeven provinciën 69.

71 Ibidem, 41, 48, and 51.

72 Ibidem. There were kosher and non-kosher meat halls in Amsterdam. See: Rädecker T.S., "Uniting and Dividing: Social Aspects of the Eighteenth - Century Ashkenazi Meat Hall in Amsterdam", Zutot: Perspectives on Jewish Culture 7 (2011) 81-88. On Leiden riots, see: Prak M. - Luiten van Zanden J., "Tax Morale and Citizenship in the Dutch Republic", in Gelderblom O. (ed.), The Political Economy of the Dutch Republic (London - New York: 2016 [2009]) 143-166, here 157-158.

73 Fuks, De zeven provinciën 48.

74 Van Eeghen I.H., "De autobiografie van Moses Salomon Asser", Jaarboek Amstelodamum (1963) $130-165$.
} 
trade during the reign of Louis I Bonaparte (1806-1810). He also pushed for the emancipation of Jews in the United Provinces. ${ }^{75}$

Unlike the undefined readership of the two previous sources, the case seems to be rather clear: Asser begins his text with 'Ik kon aan het verzoek mijner kleinkinderen mij niet onttrekken' ('I could not escape the request of my grandchildren') ${ }^{76}$ Yet, this assessment might only be partially true. Asser's text is meant to be instructive for the grandchildren and in this way resembles another Dutch text, De laatste vaderlijke lessen (The Last Fatherly Lessons) by Abraham van der Meersch. This text was written some hundred years earlier, but still seems to have a broader audience in mind. ${ }^{77}$

Asser's egodocument plays out in the heuristic zones of the mind, the house, the community, and the state. His text should be examined through this particular prism. Asser considered his life extraordinary, as he rose from a rather mediocre existence to great renown, taking on important public roles. According to him, he developed the qualities of patience and firmness - this relates directly to his mind. Wishing his grandchildren to enjoy the same success, he wanted to teach them that greatness can be achieved through patience, virtue, and personal efficiency. He writes that his story will be about

Die bijzondere standverwisselingen, die ik ondergaan heb; - het geduld, dat ik geofend, - de standvastigheid, waarmee ik de alle tegenwerkingen getorsch heb; - zal hun tot les verstrekken, dat men door geduld, deugd en werkzaamheid tot alles komen kan. - Zij zullen de waarheid bevestigd vinden van het spreekwoord: tandem bona causa triumphat. ${ }^{78}$

[t]hose special changes of position that I have undergone; - the patience I exercised, - the steadfastness with which I torched all oppositions; will teach them that everything can be achieved through patience, virtue, and action. - They will find the confirmed truth of the proverb: tandem bona causa triumphat [Lat.: A good cause triumphs in the end, MG].

Moses Salomon was born in 1754 as second child to Salomon Moses Asser (1727-?), a diamond splitter, and Gracia van Embden (1732-1757), the eldest

75 Ibidem., 13o. On the maskilim, see Rädecker T.S., MakingJews Dutch: Secular discourse and Jewish responses, 1796-1848 (Ph.D. dissertation, University of Groningen: 2015).

76 Van Eeghen, "De autobiografie" 138-139, see also the editor's comment to that statement.

77 Van der Meersch Abraham, "De laatste vaderlijke lessen, 1721", eds. P. Visser - S.B.J. Zilverberg, Doopgezinde bijdragen, nieuwe reeks 17 (1991) 153-188.

78 My italics. Van Eeghen, "De autobiografie" 139. 


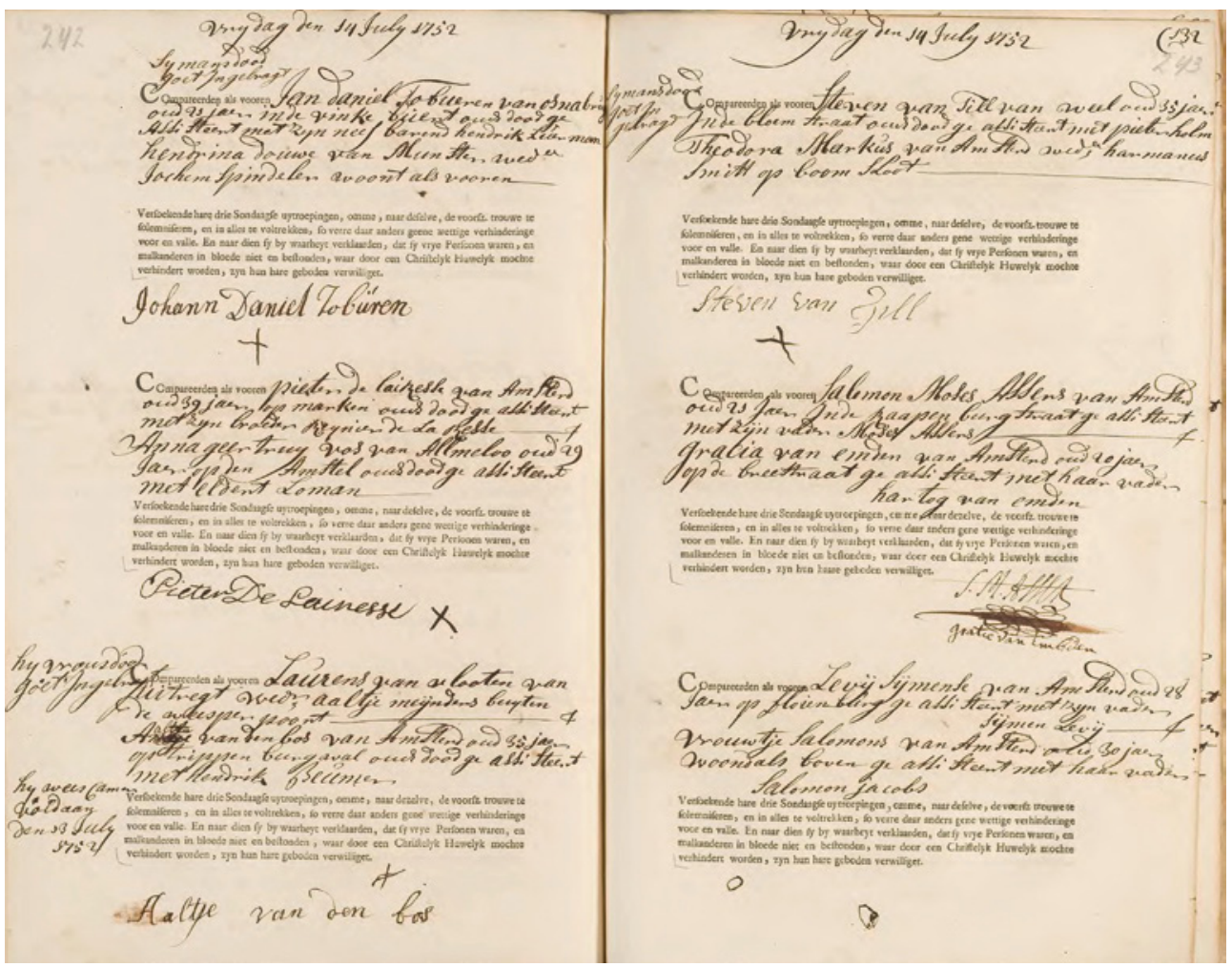

FIGURE 10.7 Marriage registration of Moses Salomon Asser and Gracia van Emdben. Marriage Register, Archives number 5001, inventory number 732, p. 243 (the middle entry on the right)

(C) CITY ARCHIVES AMSTERDAM

\section{daughter of the printer and medical doctor Naphtali Hertz Levi Rofe (Hartog} Alexander van Embden) [Fig. 10.7]. Van Embden was a learned woman. ${ }^{79}$

79 With the help of the newly digitised Notary Archives in Amsterdam, some biographical details can be reconstructed. For the marriage registration for Moses's parents, see: City Archives Amsterdam, Marriage Register, Archives number 5001, inventory number 732, p. 243, aktenummer Dтв 732: 'Vrijdag den 14 july 1752. [...] Comprareerden als voren Salomon Moses Assers van Amsterd[am] oud 25 jaer inde Raapen burg straat geassisteert met zijn vader Moses Assers. Gracia van Emden van Amsterd[am] oud 20 jaer op de Breestraat geassisteert met haar vader Hartog van Emden [...]' ('Friday 14 July $175^{2}$ [...] appeared before [me] Salomon Moses Assers of Amsterd[am] 25 years old [living at] Raapen brug street, assisted by his father Moses Assers. Gracia van Emden of Amsterd[am] 20 years old [living] on the Breestraat, assisted by her father Hardog van Emden [...]'). Signed: S.M. Asser and Gratie van Emden. This makes the birth year of Moses Salomon's father 1727 and of his mother 1732. Curiously, there is the standard printed reference to a Christian wedding held, which of course was not the case here. 
Moses Salomon's maternal grandfather as well as both of his parents belonged to the maskilim. . $^{80}$

Although Asser presents a very polished version of events, at times he slips into personal opinions, which render his writing more private. An important point is the family status. Asser stresses that his father's house was a meeting point for the maskilim, ${ }^{81}$ the Jews who had broken off with the old tradition and wanted change and progress in Jewish society. To fashion himself as an educated person in the eyes of a reader, he points out that he received a good education and that his frequent contact with various learned men allowed him to practise his scholarly interests and languages. ${ }^{82}$ Among those who attended his father's house were French refugees. He refers most likely to the Huguenots, either the first or second generation, who arrived into the United Provinces after the Revocation of the Edict of Nantes in $1685 .{ }^{83}$ Among the refugees were intellectuals - philosophers, pastors and historians - who reinforced Asser's claim to an 'enlightened' household. Here, Asser presents the importance of the house as a home, but also as a meeting place for the broader community. This intersection between the self, the home, and the community creates the private sentiment of the union of the participants, who share one space and the same passion for learning and knowledge.

The text further shows how Asser built his capital and improved his social and financial position. He writes that his maternal grandfather died in 1767 , leaving Moses Salomon as his heir of a capital of 42,0oo guilders (406,791 euro nowadays), on the condition that he reaches the age of thirty, marries, has three legally born children and that the last of them is at least one year old. ${ }^{84}$ Keeping in mind that financial information was often considered to be private

8o Van Eeghen, "De autobiografie" 139, 155, footnote 3.

81 Ibidem, 140.

82 On "self-fashioning", see: Greenblatt S., Renaissance Self-Fashioning: From More to Shakespeare (Chicago - London: 1980); Kirwan R. (ed.), Scholarly Self-Fashioning and Community in the Early Modern University (London - New York: 2013).

83 On French Calvinists or the Huguenots as they are more commonly called, during the period of $1685^{-1789}$ which was called the Désert, see Ligou D. - Joutard Ph., "Les Déserts (1685-180o)", in Mandrou R. (ed.), Histoire des protestants en France (Toulouse: 1977) 189-204; Boison D., "The Revocation of the Edict of Nantes and the Desért", in Mentzer R.A. - Van Ruymbeke B. (eds.), A Companion to the Huguenots (Leiden: 2016) 221-245. On their contribution to the Dutch intellectual milieu, see Gibbs G.C., "Some Intellectual and Political Influences of the Huguenot Emigrés in the United Provinces, c. 1680-1730", Bijdragen en mededelingen betreffende de geschiedenis der Nederlanden 90 (1975) $225^{-287}$.

84 Van Eeghen, "De autobiografie" 141. "Value of the Guilder/Euro", in Website IISH. 
and was only shown to the closest family, its inclusion here supports the idea that Asser intended his text to stay within the family. ${ }^{85}$

The rest of the text focuses on his successful development of business and even a diplomatic mission he undertook for Louis Ix (1719-179o), landgrave of Hessen-Darmstadt. Louis IX contacted him through Asser's business associate Hermanus Leonardus Bromet (1724-1812) on the issue of possibly providing regiments to the States General during the war with England in $1780 .{ }^{86}$ This state-individual relationship was supposed to help him in his future endeavours, but despite the claimed personal and commercial success, he was striving for a stable income and, as we may presume, public recognition. In 1795, during the Batavian Republic, Asser became the first procureur of Amsterdam.

It is also important to look briefly at Asser's public role within the Jewish community because it relates directly the interaction between the community and the individual. Seeing an opportunity in the recent political change with the fall of the Ancien Régime in 1795 and the proclamation of the Batavian Republic, Asser decided that it was time to act to ensure the improvement of the position of the Jews. We need to keep in mind that the Jewish community traditionally supported the Orange family, because of a certain kind of patron-client relationship that existed between them. As a reaction to this support, together with his son Carel, the aforementioned Bromet, doctor Hartog de Lemon, and banker Jacob Saportas, Asser established a society of enlightened Jews, called 'Felix Libertate', and became its head. ${ }^{87}$ This was a 'patriot', i.e. at the time an anti-Orangist movement (against the Orange-Nassau family domination of the Dutch politics) as its members hoped to take advantage of the new liberal spirit that came in the wake of the French Revolution to

85 See my discussion of finances and privacy in Green M., Le Grand Tour 1701-1703. Lettres de Henry Bentinck, vicomte Woodstock, et de son précepteur Paul Rapin-Thoyras, à Hans Willem Bentinck, comte de Portland (Paris: 2021).

86 Hermanus Leonardus Bromet was a prominent Dutch Jewish politician. For more information and secondary literature, see: Wallet B., "Bromet, Hermanus Leonard", in Biografisch Woordenboek van Nederland, 2018. [Online edition, accessed on 19 March 2020. <http:// resources.huygens.knaw.nl/bwn1780-183o/lemmata/data/Bromet $>$ ]. On the mercenary trade of Hesse and in Germany in general, see: Ingrao C., The Hessian Mercenary State. Ideas, Institutions and Reform under Frederick II, 1760-1785 (Cambridge: 1987); Franz E.G., "Landgraf Ludwig IX., der hessische 'Soldatenhandel' und das Regiment 'Royal Hesse Darmstadt'", Archiv für hessische Geschichte und Altertumskunde 35 (1977) 177-227; Wilson P.H., "The Politics of Military Recruitment in Eighteenth-Century Germany", The English Historical Review 117.472 (2002) 536-568; Wilson P.H., "The German 'Soldier Trade' of the Seventeenth and Eighteenth Centuries: A Reassessment", The International History Review 18.4 (1996) 757-792.

87 Sonnenberg-Stern, Emancipation and Poverty 44-47. 


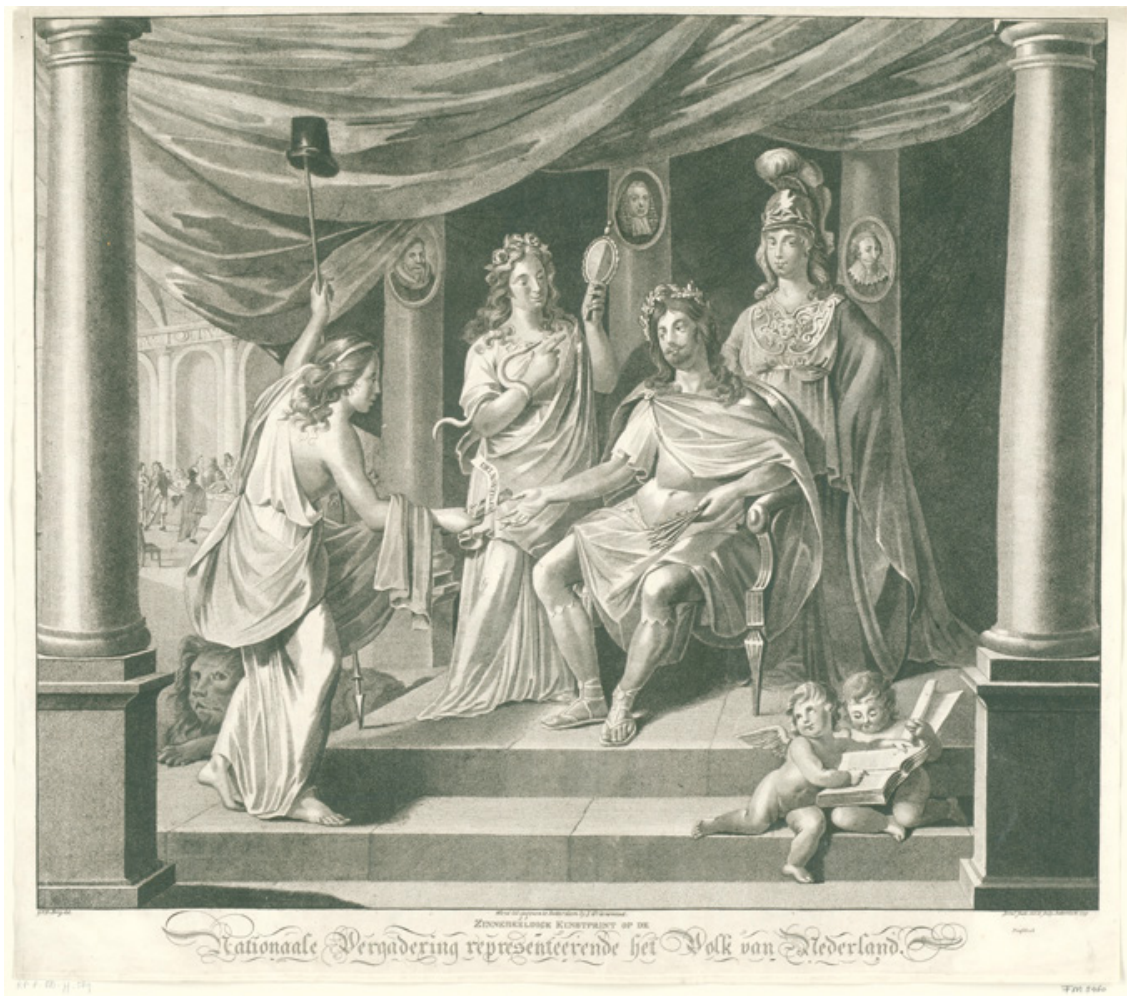

FIGURE 10.8 Jeremias Snoek after Gijsbertus Johannus van den Berg, Allegory of the National Assembly, 1796, Rotterdam, 1797. Print, 50,3 $\times 57,5 \mathrm{~cm}$

(C) RIJKSMUSEUM AMSTERDAM, OBJ. NUMBER: RP-P-OB-77.589

obtain equal rights for the Jews. Yet, the majority of the Jews and the stricter Christians opposed this society. This was due to the theological issues and the attempts of the traditional Jewish leadership to keep its ruling position among the Jews. At the same time, the city authorities refused to revoke laws that discriminated against Jews in the city. Eventually, after appealing to the National Assembly, Asser's association managed to pass the law with French help in 1796 [Fig. 10.8]. ${ }^{88}$ This action of Asser and his comrades can be seen as an example of an invasion or betrayal of the privacy of the Jewish community, where members were expected to avoid causing public controversies that could put the community in danger, especially because the traditionalists did not generally support Asser's actions. Yet, bearing in mind that privacy can be

88 Van Eeghen, "De autobiografie" 150; Sonnenberg-Stern, Emancipation and Poverty 47-49. 
a quality and a threat, in this case not taking up this cause would have been a bad service for the ultimate interests of the Jewish people.

After the emancipation of the Jews, one of the highest points of Asser's career occurred in 1808 when Louis I appointed him as part of a committee to design a law-book for commerce in the Netherlands. ${ }^{89}$ His support of the French invader cost him dearly. When Willem v of Orange (1748-1806), later King Willem I of the Netherlands, returned to the Netherlands, a new committee was created, but Asser was left out. Things improved only in 1820, when Willem I dubbed him knight of the Dutch Lion. At the end he lists his most important achievements, among them 'bezorger der Joodsche vrijheid' ('procurer of the Jewish freedom').90 Asser tells proudly how he started living in a rented house and eventually lived in one of the biggest and most luxurious houses of Amsterdam, and possessed significant wealth. Once again, the idea behind having one's own home is particularly dominant; and is here a measure of success.

To sum up, Asser provides intimate details in his account and not only informs the reader of the financial dealings but also explains his underlying motives for actions. This openness gives the text a much more private tone that that of the preceding examples.

\section{$7 \quad$ Conclusion}

The three accounts presented here were written in three different periods and demonstrate different understandings that may be taken as testimonials to the perceptions of privacy by their authors. Both De Pinto and Asser write a personal account of their own life, yet while the first and earliest text contains mostly reflections on places, the second and the third are engaged with more personal writing. Braatbard's account stands out because of its 'chronicle' genre since it is focused on describing the events and noting the news. Yet all three accounts give us a sense of several underlying ideas about what was considered private: the body, the home, and the community. These three elements feature prominently in all three authors.

What do these egodocuments tell us about Jewish perceptions of privacy in the early modern period? The "De Pinto Manuscript" reveals how the private nexus between two people was created through secrecy and friendship in order to safely escape a dangerous situation in which De Pinto found himself.

\footnotetext{
89 Van Eeghen, "De autobiografie" 153.

90 Ibidem, 154.
} 
In all three sources, we have seen that the house played an important role for individual well-being, acting as a safe space or not, based on whether it had the required dimensions of comfort and security. The attempts of the community leaders to negotiate with the local Dutch authorities in their own homes show that the well-being of the community, and as such their own, was their priority. It is also for that reason that Isaac II de Pinto mentioned in Braatbard's chronicle was willing to open his house to the stadtholder, and invite him into the 'private' sphere of the Jewish community which he represented.

The sources show how individuals were driven by the community to accept interference with their body and property to be part of the community. Circumcision, clothes, and choice of food are specifically Jewish elements of one's privacy. Importantly, Asser's autobiography shows how the privacy of the community had to be given up in order to improve the situation for the entire community, even at the cost of the betrayal of privacy. In this case, the community's privacy was a threat to its success, and Asser did not hesitate to give it up in order to improve the situation for the Jews. Thirdly, the threshold of body and community illustrates how bodily privacy had to be compromised because the body had to be altered to become part of the community and the trusted circle. This idea echoes in the account of Braatbard in the reference to the unofficial requirement that everybody must wear an orange ribbon on their clothes. Finally, the languages of two of the documents played an important role in guarding the privacy of their authors: De Pinto wrote in Spanish and Braatbard wrote in Yiddish, two languages that Dutchmen did not master, which would leave them within the privacy of their respective Jewish communities.

The unique situation of the Jews in Amsterdam since their arrival in the United Provinces and up to their emancipation as one of the most secure places in Europe at the time defines their private sphere and goals. Unlike their fellows in other European countries, Jews in Amsterdam did not live in fear for their lives, and they made considerable efforts to avoid jeopardising this position. Therefore, for the Jews in Amsterdam the community was an important element of solidarity, and its privacy was protected from the outside world by its members. These three Jewish egodocuments written in Amsterdam show that their authors saw themselves as part of both the Jewish and the Dutch milieux, yet felt the need to prove their 'worthiness' and success to their readers. Further research into Dutch egodocuments is needed for proper contextualisation, which will elucidate the differences and the similarities between notions of privacy of various religious communities residing in Amsterdam in the early modern period, and which will assess how these notions changed over time. 


\section{Bibliography}

\section{Manuscripts}

City Archives Amsterdam, Marriage Register, Archives number 50o1, inventory number 732, p. 243, aktenummer DTв 732 .

\section{Printed Works}

Aa A.J. van der, Biographisch woordenboek der Nederlanden, 21 vols. (Haarlem:

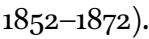

Ariès Ph. - Duby G. - Chartier R., A History of Private Life, vol. 3, trans. Goldhammer A. (Cambridge, MA - London: 1989).

Bendowska M. - Doktór J., The Amsterdam of Polish Jews: Old Hebrew Printed Works from the Collections of the Jewish Historical Institute Warsaw (Warsaw: 2016).

Berg Ch., The Classical Liberal Case for Privacy in a World of Surveillance and Technological Change (Cham: 2018).

Berger Sh., "Reading Yiddish and Lernen: Being a Pious Ashkenazi in Amsterdam, 1650-180o", in Kaplan Y. - Michman D. (eds.), The Religious Cultures of Dutch Jewry (Leiden - Boston: 2017) 124-140.

Berger Sh., "Isaac de Pinto's Testament: A Case of Multiple Images?", in Brasz Ch. - Kaplan Y. (eds.), Dutch Jews as Perceived by Themselves and by Others (Leiden Boston: 2001) 79-91.

Bicker-Raye Jacob, Het dagboek van Jacob Bicker Raye 1732-1772, eds. F. Beijerinck M.G. de Boer (Amsterdam: 1935).

Bruun M.B., The Centre for Privacy Studies Working Method, Online edition, accessed on 25 June 2020. <https://teol.ku.dk/privacy/research/work-method/privacy_work _method.pdf $>$.

Bodian M., Hebrews of the Portuguese Nation: Conversos and Community in Early Modern Amsterdam (Bloomington, IN: 1997).

Boison D., "The Revocation of the Edict of Nantes and the Desért", in Mentzer R.A. Van Ruymbeke B. (eds.), A Companion to the Huguenots (Leiden: 2016) 221-245.

Chajes J.H., "Accounting for the Self: Preliminary Generic-Historical Reflections on Early Modern Jewish Egodocuments", The Jewish Quarterly Review 95.1 (2005) 1-15.

Commelin Casparus (ed.), Beschryvinge van Amsterdam (Amsterdam, bij de Wed. Aart Dirksz Oossaan: 1694).

Costigan L.H., "The Rise of the Modern Inquisition in Portugal and Brazil, and the Transformation of Jews and New Christians into Heretics", in Prudlo D. (ed.), A Companion to Heresy Inquisitions (Leiden: 2019) 228-245.

Cowen Orlin L., Locating Privacy in Tudor London (Oxford: 2007).

De Mare H., Huiselijke taferelen: de veranderende rol van het beeld in de Gouden Eeuw (Nijmegen: 2012). 
Dekker R. - Baggerman A. (eds.), Egodocumenten van Nederlanders uit de zestiende tot begin negentiende eeuw. Repertorium (Amsterdam: 2016).

Dekker R. (ed.), Egodocuments and History: Autobiographical Writing in its Social Context since the Middle Ages (Hilversum: 2002).

Flather A., Gender and Space in Early Modern England (Woodbridge: 2007).

Franz E.G., "Landgraf Ludwig IX., der hessische 'Soldatenhandel' und das Regiment 'Royal Hesse Darmstadt', Archiv für hessische Geschichte und Altertumskunde 35 (1977) 177-227.

Frijhoff W. - Prak M. (eds.), Geschiedenis van Amsterdam, vol. 2-1: Centrum van de wereld, 1578-1650 (Amsterdam: 2004).

Fuks L., De zeven provinciën in beroering. Hoofdstukken uit een Jiddische kroniek over de Jaren 1740-1752 van Abraham Chaim Braatbard (Amsterdam: 1960).

Fuks-Mansfeld R.G., "Abraham Hayim ben Zvi Hirsh Braatbard. A Hebrew Type-Setter in Amsterdam in the First Half of the Eighteenth Century", Zutot 1.1 (2001) 133-137.

Fuks-Mansfeld R.G., De Sefardim in Amsterdam tot 1795. Aspecten van een joodse minderheid in een Hollandse stad (Hilversum: 1989).

Gibbs G.C., "Some Intellectual and Political Influences of the Huguenot Emigrés in the United Provinces, c. 1680-1730", Bijdragen en mededelingen betreffende de geschiedenis der Nederlanden 90 (1975) 225-287.

Green M., Le Grand Tour 1701-1703. Lettres de Henry Bentinck, vicomte Woodstock, et de son précepteur Paul Rapin-Thoyras, à Hans Willem Bentinck, comte de Portland (Paris: 2021).

Green M., "Spaces of Privacy in Early Modern Amsterdam", Tijdschrift voor Sociaale en Economische Geschiedenis 18.3 (2021) 17-40.

Greenblatt S., Renaissance Self-Fashioning: From More to Shakespeare (Chicago London: 1980).

Grotius Hugo, Hugo Grotius's Remonstrantie of 1615. Facsimile, Transliteration, Modern Translations and Analysis, trans., eds. D. Kromhout - A. Offenberg (Leiden: 2019).

Huussen A.H., "The Legal Position of the Jews in the Dutch Republic c. 1590-1796", in Israel J. - Salverda R. (eds.) Dutch Jewry: Its History and Secular Culture (1500-2000) (Leiden: 2002) 25-42.

Ingrao C., The Hessian Mercenary State. Ideas, Institutions and Reform under Frederick II, $1760-1785$ (Cambridge: 1987).

Israel J.I., "The Republic of the United Netherlands Until About 1750: Demography and Economic Activity", in Blom J.C.H. - Fuks-Mansfeld R.G. - Schöffer I. (eds.), The History of the Jews in the Netherlands (Liverpool: 2007) 85-115.

Israel J.I., The Dutch Republic: Its Rise, Greatness and Fall 1477-1806 (Oxford: 1995).

Israel J.I., "The Changing Role of the Dutch Sephardim in International Trade, 15951715", in Michman J. - Levie T. (eds.), Dutch Jewish History: Proceedings of the 
Symposium on the History of the Jews in the Netherlands November 28-December 3 , 1982, Tel Aviv - Jerusalem (Jerusalem: 1984) 31-52.

Kaplan Y., "Gente Política: The Portuguese Jews of Amsterdam vis-à-vis Dutch Society", in Brasz Ch. - Kaplan Y. (eds.), Dutch Jews as Perceived by Themselves and by Others: Proceedings of the Eighth International Symposium on the History of the Jews in the Netherlands (Leiden - Boston - Cologne: 2001) 21-40.

Kaplan Y., "The Portuguese Community in 17th-century Amsterdam and the Ashkenazi World", in Michman J. (ed.) Dutch Jewish History: Proceedings of the Fourth Symposium on the History of the Jews in the Netherlands 7-10 December - Tel-AvivJerusalem, 1986, vol. 2 (Assen - Maastricht: 1989) 23-46.

Kaplan Y., "Amsterdam and the Ashkenazi Migration in the Seventeenth Century", Studia Rosenthaliana 23 (1989) 22-44.

Kennedy J.C., A Concise History of the Netherlands (Cambridge: 2017).

Kirwan R. (ed.), Scholarly Self-Fashioning and Community in the Early Modern University (London - New York: 2013).

Levie Bernfeld T., Poverty and Welfare Among the Portuguese Jews in Early Modern Amsterdam (Oxford: 2012).

Levine A., Sensual Philosophy: Toleration, Skepticism, and Montaigne's Politics of the Self (Lanham - Boulder - New York - London: 2001).

Levine A., "Skepticism, Self, and Toleration in Montaigne's Political Thought", in Levine A. (ed.), Early Modern Skepticism and the Origins of Toleration (Lanham - Boulder New York - London: 1999) 51-77.

Ligou D. - Joutard Ph., "Les Déserts (1685-180o)", in Mandrou R. (ed.), Histoire des protestants en France (Toulouse: 1977) 189-204.

Margulis S.T., "Privacy as a Social Issue and Behavioral Concept", Journal of Social Issues $59.2(2003) 243^{-261 .}$

Michels E., Jiddische Handschriften der Niederlande (Leiden - Boston: 2013).

Nijenhus I.J.A., Nijenhuis, Een joodse philosophe. Isaac de Pinto (1717-1787) en de ontwikkeling van de politieke economie in de Europese Verlichting (Amsterdam: 1992).

Prak M. - Luiten van Zanden J., "Tax Morale and Citizenship in the Dutch Republic", in Gelderblom O. (ed.), The Political Economy of the Dutch Republic (London - New York: 2016 [2009]) 143-166.

Rädecker T.S., Making Jews Dutch: Secular discourse and Jewish responses, 1796-1848 (Ph.D. dissertation, University of Groningen: 2015).

Rädecker T.S., "Uniting and Dividing: Social Aspects of the Eighteenth-Century Ashkenazi Meat Hall in Amsterdam", Zutot: Perspectives on Jewish Culture 7 (2011) 81-88.

Rowen H.H., The Princes of Orange: The Stadholders in the Dutch Republic (Cambridge New York: 1988) 163-185. 
Salomon H.P., “The 'De Pinto' Manuscript: A 17th Century Marrano Family History”, Studia Rosenthaliana 9.1 (1975) 1-62.

Schreuder Y., Amsterdam's Sephardic Merchants and the Atlantic Sugar Trade in the Seventeenth Century (Newark, DE: 2019).

Schuurman A. - Spierenburg P. (eds.), Private Domain, Public Inquiry: Families and Life-styles in the Netherlands, 1500 to the Present (Hilversum: 1996).

Sluys D.M., "Hoogduits - Joods Amsterdam van 1635 tot 1795", in Brugmans H. - Frank A. (eds.), Geschiedenis der Joden in Nederland (Amsterdam: 1940).

Sonnenberg-Stern K., Emancipation and Poverty: The Ashkenazi Jews of Amsterdam, 1796-1850 (Houndmills - London: 2000).

Sorkin D., "Beyond the East-West Divide: Rethinking the Narrative of the Jews' Political Status in Europe, 1600-1750", Jewish History 24 (2010) 247-256.

Strum D., Princípios da economia política Judaica: as reflexões políticas de Isaac de Pinto (Ph.D. dissertation, Hebrew University of Jerusalem: 200o).

Tarlow S., Ritual, Belief and the Dead in Early Modern Britain and Ireland (Cambridge: 2011).

Teller A., "Jewish Women in the Wake of The Chmielnicki Uprising: Gzeies Tah-tat as a Gendered Experience", in Cohen R.I. - Dohrmann N.B. - Shear A. - Reiner E. (eds.), Jewish Culture in Early Modern Europe: Essays in Honour of David B. Ruderman (Cincinnati, OH: 2014) 39-49.

Troost W., William III, the Stadholder-King: A Political Biography, trans. Grayson J.C. (Aldershot - Burlington: 2005).

Trull M.E., Performing Privacy and Gender in Early Modern Literature (Houndmills: 2013).

Van den Heuvel Ch., 'De Huysbou': A Reconstruction of an Unfinished Treatise on Architecture, Town Planning and Civil Engineering by Simon Stevin (Amsterdam: 2005).

Van der Meersch Abraham, "De laatste vaderlijke lessen, 1721", eds. P. Visser - S.B.J. Zilverberg, Doopgezinde bijdragen, nieuwe reeks 17 (1991) 153-188.

Van Eeghen I.H., "De autobiografie van Moses Salomon Asser", Jaarboek Amstelodamum (1963) 130-165.

Wallet B., "Bromet, Hermanus Leonard", in Biografisch Woordenboek van Nederland, 2018. Online edition, accessed on 19 March 2020. <http://resources.huygens.knaw .nl/bwn1780-183o/lemmata/data/Bromet>.

Wallet B., Links in a Chain: Early Modern Yiddish Historiography in the Northern Netherlands (1743-1812) (Ph.D. dissertation, University of Amsterdam: 2012).

Wheelock (Jr.) A.K. - Seeff A.F. (eds.), The Public and Private in Dutch Culture of the Golden Age (Newark - London: 2000).

Wilson P.H., "The Politics of Military Recruitment in Eighteenth-Century Germany", The English Historical Review 117.472 (2002) 536-568. 
Wilson P.H., “The German 'Soldier Trade' of the Seventeenth and Eighteenth Centuries: A Reassessment", The International History Review 18.4 (1996) 757-792.

Zwiers A., "Inventory of the Moveable Property of the Ashkenazi Community of Amsterdam, 1788", Studia Rosenthaliana 37 (2004) 309-397.

Zwiers A.D., "Amsterdam Yiddish in Diary and Chronicle", Studia Rosenthaliana 30.2 (1996) 233-253.

\section{Websites}

International Institute of Social History. Online edition, accessed on 14 April 2020. $<$ http://www.iisg.nl/hpw/calculate.php $>$. 